\title{
Promoter hypermethylation and protein expression of the p16 gene: analysis of 43 cases of B-cell primary gastric lymphomas from China
}

\author{
Qin Huang ${ }^{1}$, Lingbao $\mathrm{Ai}^{2}$, Zackery Y Zhang ${ }^{1}$, Chun-Yang Fan ${ }^{2}$ and Lawrence M Weiss ${ }^{1}$ \\ ${ }^{1}$ Division of Pathology, City of Hope National Medical Center, Duarte, CA, USA and ${ }^{2}$ Department of Pathology \\ University of Arkansas for Medical Sciences, Little Rock, AR, USA
}

\begin{abstract}
The p16 (CDKN2a/INK4a) gene is an important tumor-suppressor gene, involved in the p16/cyclin-dependent kinase/retinoblastoma gene pathway of cell cycle control. The p16 protein is considered to be a negative regulator of the pathway. Promoter hypermethylation resulting in inactivation of the $p 16$ gene has been found in various hematopoietic malignancies, including non-Hodgkin's lymphoma, and may play a role in transformation/clinical aggressiveness of those tumors. However, the p16 protein expression in primary gastric lymphoma has not been studied. In this study, we characterize protein expression and promoter hypermethylation of the p16 gene in B-cell primary gastric lymphomas from China. In all, 43 cases of B-cell primary gastric lymphoma were investigated. They consisted of $24(56 \%)$ cases of diffuse large-cell lymphoma, $12(28 \%)$ cases of extranodal marginal zone lymphoma, six $(14 \%)$ cases of extranodal marginal zone lymphoma with large-cell transformation and one (2\%) case of follicular lymphoma. Loss of p16 protein expression was found in 34 (79\%) out of 43 cases, while the remaining nine $(21 \%)$ cases showed positivities for the p16 protein. All 43 cases were further characterized by methylation-specific polymerase chain reaction (PCR) to analyze p16 promoter hypermethylation status. In total, $11(26 \%)$ of 43 cases were positive for p16 promoter hypermethylation. Among those, $10(30 \%)$ out of the 33 cases negative for the p16 immunostaining showed promoter hypermethylation, whereas only one (10\%) out of the 10 cases that were positive for the p16 immunostaining displayed promoter hypermethylation. Of the $\mathbf{4 3}$ cases, $\mathbf{3 0}$ had limited pathologic data at the time of resection. Primary gastric lymphoma involved extragastric sites (lymph node or liver) in $17(57 \%)$ of 30 cases, while the remaining $13(43 \%)$ cases were only limited to the stomach. Loss of p16 protein expression was found in $14(82 \%)$ of 17 cases with extragastric involvement and in $11(85 \%)$ of 13 cases without such involvement. In conclusion, loss of p16 protein expression is frequent in those B-cell primary gastric lymphomas and approximately one-third of such loss correlated with promoter hypermethylation. Despite limited pathologic data, loss of p16 protein expression appears not to be correlated with extragastric involvements.
\end{abstract}

Modern Pathology (2004) 17, 416-422, advance online publication, 13 February 2004; doi:10.1038/modpathol.3800072

Keywords: primary gastric lymphoma; $p 16$ gene expression; promotor hypermethylation

The p16 (CDKN2a/INK4a) gene is an important tumor-suppressor gene, involved in the $p 16 /$ cyclindependent kinase/retinoblastoma gene pathway of cell cycle control, in which the p16 protein is considered to be a negative regulator involved in the inhibition of G1 phase progression. ${ }^{1}$ The human p16

Correspondence: Q Huang, MD, PhD, Division of Pathology, City of Hope National Medical Center, Duarte, CA 91010, USA.

E-mail: qhuang@coh.org

This work was presented in part at the 92nd Annual Meeting of the United States and Canadian Academy of Pathology in Washington, DC, March 22-28, 2003.

Received 14 May 2003; revised 31 October 2003; accepted 11 November 2003; published online 13 February 2004 protein contains 156 amino acids and was first discovered in a yeast two-hybrid system to detect proteins that interact with human cyclin-dependent kinase. ${ }^{2}$ The tumor-suppressor function of $p 16$ is attributed to its ability to inhibit the catalytic activity of the cyclin-dependent kinase 4-6/cyclin $\mathrm{D}$ complex that is required for phosphorylation of retinoblastoma protein. ${ }^{3,4}$ Inactivation of $p 16$ gene plays an important role not only in tumorigenesis but is also considered to be a poor prognostic event in certain malignancies. ${ }^{1-4}$ DNA methylation is a frequent mechanism of transcriptional silencing in human cancer. ${ }^{5}$ Recently, aberrant methylation of multiple promoter-associated $\mathrm{CpG}$ islands of 
tumor-suppressor genes has been found in a variety of human malignancies. Promoter hypermethylation, in addition to gene deletion and point mutation of $p 16$ locus, has been found to be one of the main mechanisms of $p 16$ inactivation. ${ }^{6-9}$ Hypermethylation of the $5^{\prime} \mathrm{CpG}$ islands of $p 16$ gene promotor region has been reported in colon, bladder, breast, head and neck, and lung carcinoma as well as in glioma, melanoma, leukemia and lymphoma. ${ }^{10-15} \mathrm{In}$ a previous study, we analyzed the histologic and immunologic features of primary gastric lymphomas from China and suggested that nuclear BCL10 expression may predict a poor prognosis with early extragastric involvement. ${ }^{16}$ However, the status of p16 expression in these lymphomas has not been studied. In this study, p16 protein expression patterns were analyzed and promoter methylation of $p 16$ gene in these primary gastric lymphomas was characterized.

\section{Materials and methods}

\section{Tissue Acquisition}

Paraffin-embedded tissues of resection $(n=39)$ and biopsy $(n=4)$ specimens of 43 primary gastric lymphomas were obtained from the files between 1996 and 2000 in Cancer Hospital, Chinese Academy of Medical Sciences and Qindao University Hospital. Diagnosis was verified by City of Hope pathologists using the recent WHO (World Health Organization) classification. ${ }^{17}$ The available pathologic data concerning the status of extragastric involvement (such as lymph node and liver) at the time of surgical resection were also reviewed.

\section{Immunohistochemical Staining for the p16 Protein}

Immunohistochemical staining was performed using a monoclonal antibody against the p16 protein (Ab-4, clone 16P04 or JC2; NeoMarkers, Fremont, CA, USA). Positive p16 expression was defined as clear, nuclear and cytoplastic staining. The p16 immunohistochemical staining results were interpreted as follows: positive $(+)$, if positive immunohistochemical staining in both nuclei and cytoplasm is present in more than 50\% tumor cells; and negative (-), if positive p16 immunohistochemical staining is present in less than $10 \%$ tumor cells. The positive p16 immunohistochemical staining case typically consists of more than $50 \%$ of strongly stained tumor cells, whereas the negative p16 immunohistochemical staining case contains either no positive cells or in rare cases, less than $10 \%$ weakly stained tumor cells. In our study, cases are fairly easily separated into the positive or negative group because they either showed well-recognizable strong and diffuse stains (positive) or faint, scattered staining that is difficult to spot (negative). We did not encounter cases with staining intensity and percentage that fell between the criteria outlined above for positive and negative cases. Known positive and negative cases from our previous studies on head and neck carcinoma were used as control. ${ }^{18}$ Two pathologists (QH and CYF) evaluated the immunohistochemical staining results independently.

\section{Sample Collection and DNA Extraction}

DNA samples were collected using the EX-WAX DNA Extraction Kit (Intergen Co.,. New York, NY, USA) from one $5-\mu$ m-thick tissue section, scratched from a glass slide. Human placental DNA (Sigma) was used as a negative control and CpGenome universal methylated human DNA (Intergen Co., New York, NY, USA) served as a positive control.

\section{Bisulfite Modification of DNA for Methylation- specific PCR}

DNA samples from the primary gastric lymphomas, negative and positive controls, respectively, were subjected to bisulfite modification prior to methylation-specific PCR using a CpGenome ${ }^{\mathrm{TM}}$ DNA modification Kit (Intergen Co., New York, NY, USA).

\section{PCR Amplification and Primers}

Amplification of the promoter region of the $p 16$ gene was carried out in a Touchgene Gradient Thermal Cycler (Techne Inc., Princeton, NJ, USA) in a $50 \mu \mathrm{l}$ PCR reaction mixture containing $2 \mu$ l of bisulfitetreated genomic DNA, dinucleotide triphospates (dNTPs) (each at $200 \mu \mathrm{M}$ ), primers (50 pmol each per reaction), $2.5 \mathrm{mM} \mathrm{MgCl}$ and $1.25 \mathrm{U}$ Hotstar Taq (Qiagen, Valencia, CA, USA) in $1 \times$ PCR buffer. All reagents were supplied with the Qiagen Hotstar Taq Kit (Qiagen, Valencia, CA, USA). The only exception was the dNTP mix (Roche Molecular Biochemicals, Indianapolis, IN, USA).

Primers for $p 16$ gene were designed as follows: $5^{\prime}$ TTA TTA GAG GGT GGG GTG GAT TGT-3' (sense) and 5'-CAA CCC CAA ACC ACA ACC ATA A-3' (antisense) for the unmethylated reactions; $5^{\prime}$-TTA TTA GAG GGT GGG GCG GAT CGC-3' (sense) and 5'-GAC CCC CGA ACC GCG ACC GTA A-3' (antisense) for the methylated reactions as described previously. ${ }^{8,15}$ Both primers were purchased from Operon Technologies Inc. (Alameda, CA, USA). The PCR conditions were as follows: initial denaturation and hot start at $95^{\circ} \mathrm{C}$ for $15 \mathrm{~min}$, then 40 cycles consisting of $30 \mathrm{~s}$ at $95^{\circ} \mathrm{C}, 30 \mathrm{~s}$ at $60^{\circ} \mathrm{C}$ (unmethylated reactions) or $65^{\circ} \mathrm{C}$ (methylated reactions) and $1 \mathrm{~min}$ at $72^{\circ} \mathrm{C}$ followed by a final 5 -min extension at $72^{\circ} \mathrm{C}$. Positive and negative control DNA samples and controls without DNA were used for each set of PCRs. 


\section{Subcloning and DNA Sequencing of PCR Products}

Amplified PCR products were ligated into a pCR4TOPO vector and transformed into Escherichia coli (E. coli) using TOPO TA cloning Kit for sequencing (Invitrogen Life Technologies, Carlsbad, CA, USA). Plasmid DNA isolated from E. coli colonies was sequenced using an Applied Biosystems (Foster City, CA, USA) Model 377 DNA Sequencer as previously described. ${ }^{19}$ The templates used for the sequencing were at $100 \mathrm{ng} / \mu \mathrm{l}$. A T3 universal primer was used in all reactions at $1.6 \mu \mathrm{M}$. The Applied Biosystems Dye Terminator Kit version 2.0 was used according to the manufacturer's instructions.

\section{Results}

\section{Histopathology of the Primary Gastric Lymphomas}

The mean age for the patients was 51 years with a range from 15 to 77 years. The male/female ratio was 26:17. All 43 primary gastric lymphomas were of Bcell lineage demonstrated by immunohistochemistry analysis. Histologically, they consisted of $24(56 \%)$ cases of diffuse large-cell lymphoma, 12 (28\%) cases of extranodal marginal zone lymphoma, six (14\%) cases of extranodal marginal zone lymphoma with large-cell transformation and one $(2 \%)$ case of follicular lymphoma (Figure 1). The extranodal marginal zone lymphoma with large-cell transformation is defined by the presence of large aggregates or sheets of large lymphoid cells adjacent to the otherwise typical extranodal marginal zone lymphoma. The lymphomas expressed various B-cell-associated antigens, but all were positive for CD20. Some cases expressed CD23 (2/43), BCL-2 (31/43) and BCL-6 (16/43), and a subset also showed coexpression of T-cell-related antigen CD43 (13/43). Helicobacter pylori ( $H$. pylori) organisms were detected in $88 \%$ of all cases by histologic examination on hematoxylin and eosin (H \& E)-stained sections.

\section{p16 Protein Expression by Immunohistochemistry}

The expression of p16 protein was analyzed by immunohistochemistry using a specific antibody reacting against p16 protein. Loss of p16 protein expression (negative) was found in $34(79 \%)$ out of 43 cases, while the remaining nine cases $(21 \%)$ showed p16 protein expression (positive) in lymphoma cells (Figure 2). Among these 34 p16 immunostaining negative cases, there were 18 cases of diffuse large-cell-lymphoma, five cases of marginal zone lymphoma/diffuse large-cell lymphoma and 11 cases of marginal zone lymphoma.

\section{p16 Gene Promoter Hypermethylation by Methylation- specific PCR Analysis}

All 43 cases were further characterized by methylation-specific PCR analysis to analyze $p 16$ promoter hypermethylation status. In all, 11 (26\%) of 43 cases were positive for $p 16$ promoter hypermethylation. Among these, 10 out of the 33 cases negative for the p16 protein immunostaining showed promoter hypermethylation, whereas only one $(10 \%)$ out of
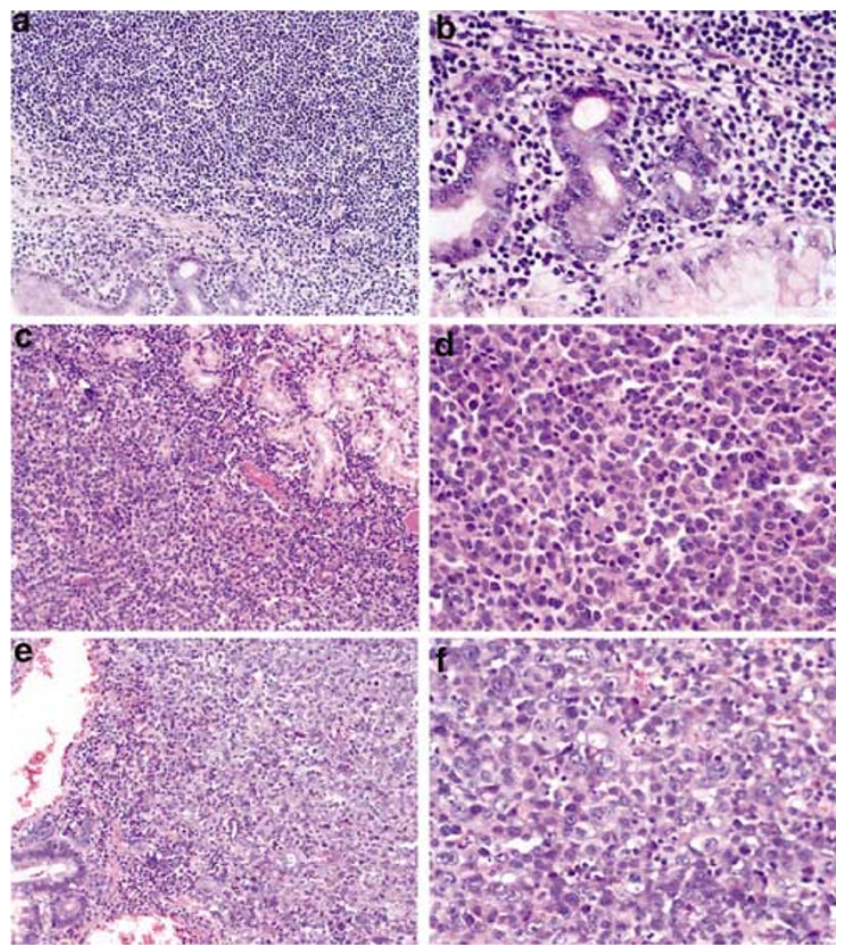

Figure 1 Histologic analysis of primary gastric lymphomas from China. Marginal zone lymphoma (MZL) of case \#39 at low magnification $(\times 200)($ a) and high magnification $(\times 400)(b)$; marginal zone lymphoma with large-cell transformation (MZL/ DLCL) of case \#36 at low magnification $(\times 200)(\mathbf{c})$ and high magnification $(\times 400)(d)$; diffuse large-cell lymphoma (DLCL) of case \#25 at low magnification $(\times 200)(\mathbf{e})$ and high magnification $(\times 400)(f)$.

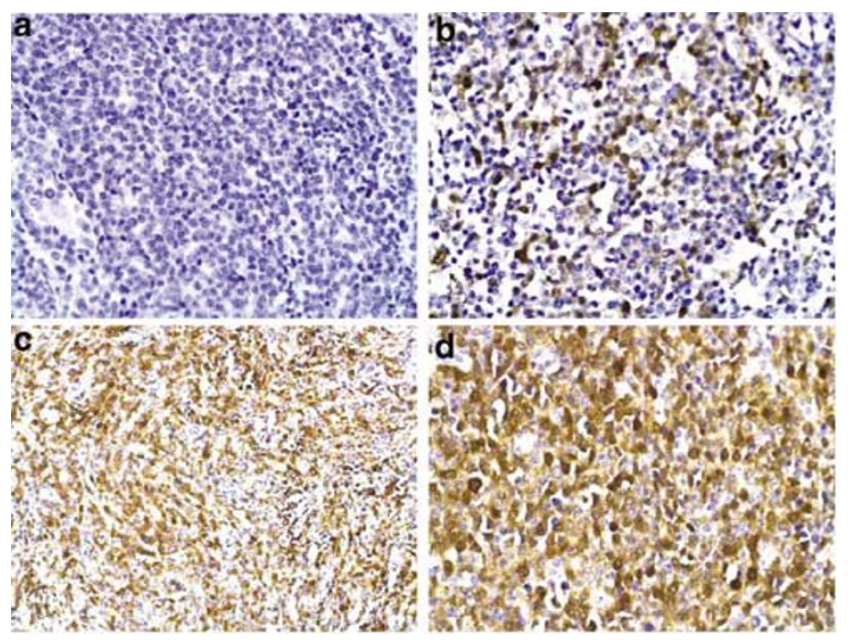

Figure 2 Immunohistochemical analysis for p16 expression in primary gastric lymphomas. (a) Negative staining of case \#30 ( $\times$ 400); (b) Focal positivity for p16 expression of case \#40 $(\times 400)$; (c) Diffuse positivity of p16 expression of case \#5 $(\times 200)$ and $(\mathbf{d})$ Diffuse positivity of p16 expression of case \#3 $(\times 400)$. 
the 10 cases that were positive for the p16 protein immunostaining displayed promoter hypermethylation (Figure 3; Table 1). The methylation status of

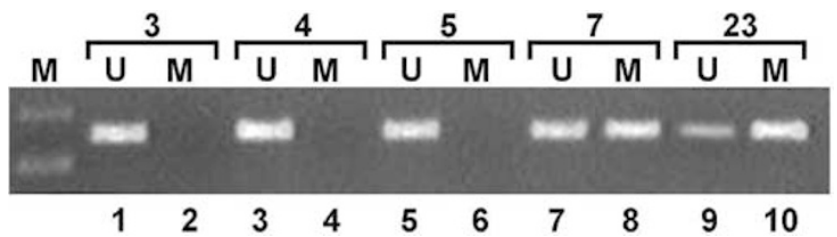

Figure 3 Bisulfite-modified genomic DNA harvested from cases \#3 (lanes 1,2), \#4 (lanes 3,4), \#5 (lanes 5,6), \#7 (lanes 7,8) and \#23 (lanes 9,10) was used in PCR reactions with the unmethylated-(U) or methylated-specific (M) primer sets. the methylation-specific products was confirmed by direct DNA sequencing (Figure 4)

\section{Correlation of p16 Protein Expression with Available Pathologic Data}

Of the 43 cases, 30 resection specimens had available pathologic data. Primary gastric lymphomas involved extragastric sites (lymph node or liver) in $17(57 \%)$ of 30 cases, while the remaining 13 cases $(43 \%)$ were limited to the stomach only at the time of resection. Absence of p16 protein expression was found in $14(82 \%)$ of 17 cases with extragastric involvement and in 11 (85\%) of 13 cases without such involvement (Table 1).

Table 1 Summary of pathologic and experimental data in 43 PGL patients

\begin{tabular}{|c|c|c|c|c|c|c|}
\hline Case no. & Sex & Age & Diagnosis & $L N$ & p16 IHC & p16 MSP \\
\hline Case 1 & $\mathrm{~F}$ & 15 & DLCL & $2 / 9$ & - & - \\
\hline Case 2 & $\mathrm{~F}$ & 42 & DLCL & NA & - & - \\
\hline Case 3 & $\mathrm{~F}$ & 40 & DLCL & $3 / 12$ & + & - \\
\hline Case 4 & $\mathrm{M}$ & 31 & DLCL & $3 / 20$ & + & - \\
\hline Case 5 & $\mathrm{~F}$ & 35 & DLCL/MZL & NA & + & - \\
\hline Case 6 & $\mathrm{M}$ & 65 & DLCL & NA & - & - \\
\hline Case 7 & $\mathrm{M}$ & 66 & DLCL & $0 / 13$ & - & + \\
\hline Case 8 & $\mathrm{M}$ & 77 & DLCL & NA & + & - \\
\hline Case 9 & $\mathrm{~F}$ & 36 & MZL & NA & - & + \\
\hline Case 10 & $\mathrm{~F}$ & 52 & DLCL & NA & - & - \\
\hline Case 11 & $\mathrm{M}$ & 38 & MZL & $0 / 4$ & + & - \\
\hline Case 12 & $\mathrm{M}$ & 70 & DLCL & NA & - & - \\
\hline Case 13 & $\mathrm{M}$ & 71 & DLCL & $10 / 23$ & - & - \\
\hline Case 14 & $\mathrm{~F}$ & 62 & DLCL/MZL & $15 / 23$ & - & + \\
\hline Case 15 & $\mathrm{~F}$ & 48 & DLCL & NA & - & - \\
\hline Case 16 & $\mathrm{~F}$ & 49 & DLCL & NA & + & - \\
\hline Case 17 & $\mathrm{M}$ & 64 & DLCL/MZL & $0 / 15$ & - & - \\
\hline Case 18 & $\mathrm{M}$ & 55 & DLCL & Liver $^{\mathrm{a}}$ & - & - \\
\hline Case 19 & $\mathrm{M}$ & 80 & MZL & NA & + & + \\
\hline Case 20 & $\mathrm{M}$ & 75 & MZL & $2 / 4$ & - & + \\
\hline Case 21 & $\mathrm{M}$ & 39 & MZL & NA & - & - \\
\hline Case 22 & $\mathrm{M}$ & 69 & DLCL & $4 / 25$ & - & - \\
\hline Csae 23 & $\mathrm{~F}$ & 54 & DLCL & $20 / 40$ & - & + \\
\hline Case 24 & $\mathrm{M}$ & 51 & MZL & $0 / 37$ & - & + \\
\hline Case 25 & $\mathrm{M}$ & 63 & DLCL & NA & - & - \\
\hline Case 26 & $\mathrm{M}$ & 57 & FL & $3 / 25$ & + & - \\
\hline Case 27 & $\mathrm{M}$ & 65 & MZL & $0 / 37$ & - & - \\
\hline Case 28 & $\mathrm{~F}$ & 49 & DLCL & $0 / 12$ & - & - \\
\hline Case 29 & $\mathrm{~F}$ & 40 & MZL & $14 / 37$ & - & - \\
\hline Case 30 & $\mathrm{M}$ & 51 & DLCL & $18 / 37$ & - & + \\
\hline Case 31 & $\mathrm{M}$ & 64 & DLCL & $17 / 34$ & - & - \\
\hline Case 32 & $\mathrm{~F}$ & 45 & MZL & $0 / 16$ & - & - \\
\hline Case 33 & $\mathrm{M}$ & 74 & MZL & $2 / 24$ & - & - \\
\hline Case 34 & $\mathrm{~F}$ & 69 & DLCL & $0 / 8$ & + & - \\
\hline Case 35 & $\mathrm{M}$ & 50 & MZL & $0 / 17$ & - & - \\
\hline Case 36 & $\mathrm{~F}$ & 38 & DLCL/MZL & $26 / 26$ & - & - \\
\hline Case 37 & $\mathrm{~F}$ & 52 & DLCL/MZL & $0 / 25$ & - & - \\
\hline Case 38 & M & 49 & DLCL & $7 / 10$ & - & - \\
\hline Case 39 & $\mathrm{~F}$ & 65 & MZL & $15 / 42$ & - & - \\
\hline Case 40 & $\mathrm{M}$ & 45 & DLCL & $0 / 24$ & + & - \\
\hline Case 41 & $\mathrm{M}$ & 43 & DLCL & $0 / 23$ & - & + \\
\hline Case 42 & $\mathrm{M}$ & 43 & DLCL/MZL & $0 / 16$ & - & + \\
\hline Case 43 & M & 60 & DLCL & NA & - & + \\
\hline
\end{tabular}

aliver involvement.

LN: lymph node status (' $X / Y$ '; $X=$ number of nodes positive for lymphoma involvement; $Y=$ total number of lymph nodes); IHC: immunohistochemical staining; MSP: methylation-specific PCR; DLCL: diffuse large-cell lymphoma; MZL: marginal zone lymphoma; FL: follicular lymphoma; NA: data not available. 
W: 5' -AGCCGGCGGCGGGGAGCAGCATGGAGCCTTCGGCTGACTGG-3'

U: 5' -AGTTGGTGGTGGGGAGTAGTATGGAGTTTTTGGTTGATTGG-3'
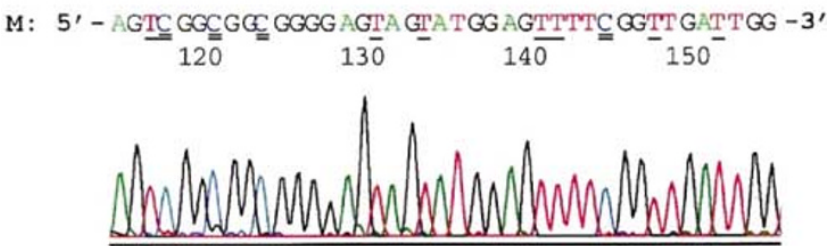

Figure 4 DNA sequence of methylation-specific PCR products: W, a wild-type DNA sequence; U, bisulfite-modified unmethylated DNA sequence. All cytosines (C) are converted to thymines (T) following bisulfite modification (single underlined). M, bisulfitemodified methylated DNA sequence (chromatogram from a cloned DNA sample from case 7 in Figure 3 and Table 1). All cytosines (C) at the non-CpG sites are converted to thymines (T) following bisulfite modification (single underlined). By contrast, all cytosines (C) at the CpG sites are methylated, and as a result, they remain as cytosines (C) following bisulfite modification (double underlined).

\section{Discussion}

The development of primary gastric lymphoma is believed to be a multistep process in which genetic and epigenetic events accumulate as a result of chronic exposure to antigen stimulation, leading eventually to clonal expansion, resulting from a loss of cell cycle control, selected cell growth and finally the development of clinically overt cancer. ${ }^{20,21}$ Primary gastric lymphoma in Western countries is largely composed of marginal zone B-cell lymphoma of mucosa-associated lymphoid tissue (MALT), which is closely related to $H$. pylori infection..$^{20,21}$ Primary gastric lymphoma development is considered to be a series of genomic aberrations that contribute, step by step, to increasing genomic instability and the ultimate establishment of a population of autonomously growing neoplastic cells. ${ }^{20}$ The translocation $\mathrm{t}(11 ; 18)$ (q21;q21) was identified in a fraction of low-grade MALT lymphoma cases, ranging from 21 to $60 \%$ of examined tumors. ${ }^{21}$ The translocation $\mathrm{t}(1 ; 14)$ involving BCL10 oncogene was described as another characteristic abnormality in low-grade MALT lymphoma, albeit at a much less frequency. ${ }^{22,23}$ Recent studies suggested that $\mathrm{t}(11 ; 18)$ translocation, closely associated with nuclear BCL10 expression, was correlated with advanced MALT lymphoma, which might not respond to anti-H. pylori therapy. ${ }^{22,23}$

In present study, we found that the lack of p16 protein expression is quite frequent $(79 \%)$ in primary gastric lymphoma from China. Although the p16 protein expression status of primary gastric lymphomas is not known in the literature, the frequency of $p 16$ inactivation in this study appears to be somewhat higher than that in previous studies on other site B-cell lymphomas/leukemias of
Western population. Sanchez-Beato et $a l^{24}$ detected inactivation of $p 16$ in $43.5 \%$ cases of aggressive diffuse large-cell lymphoma, Dalle et $a l^{25}$ found loss of $p 16$ expression in $38.1 \%$ of acute lymphoblastic leukemia and Child et $a l^{26}$ identified $43 \%$ p16 inactivation in cutaneous B-cell lymphoma. Further studies would be needed to compare the frequency of p16 inactivation of primary gastric lymphomas in the Western population. The relationship of p16 inactivation or aberrant genetic or epigenetic changes of the $p 16$ gene with tumor progression or patient survival has been investigated in various forms of human tumor, such as breast cancer, ${ }^{26,27}$ cutaneous melanoma, ${ }^{28,29}$ colorectal carcinoma, ${ }^{10}$ central nervous system malignancies, ${ }^{29-31}$ lung cancer, ${ }^{12}$ and head and neck carcinoma ${ }^{32,33}$ with no general consensus. However, there appears to be evidence supporting a role for $p 16$ inactivation in the transformation of low-growth fraction lymphomas into their aggressive variants. ${ }^{34,35}$ The histological progression of follicular lymphoma to aggressive large-cell lymphoma is frequently accompanied by 9 p21 deletions that often result in reduction or loss of p16 expression. In mantle cell lymphoma, $p 16$ deletions are associated with aggressive forms, a finding that suggests the possibility that cyclin D1 overexpression and p16 inactivation might not be completely redundant alterations. ${ }^{36}$

Mechanisms of $p 16$ silencing include loss of heterozygosity, homozygous deletion, point mutation and promoter region hypermethylation. The latter appears to be a major reason for $p 16$ inactivation in many previous studies. There appears to be good agreement of $p 16$ promoter methylation with lack of protein expression in B-cell lymphomas. ${ }^{24}$ Sanchez-Beato et $a l^{24}$ found that $p 16$ inactivation was seen in $27(44 \%)$ out of 62 cases of aggressive B-cell lymphomas as a result of hypermethylation (20 of 62 cases), 9p21 deletion (seven of 44 cases) or p16 mutation (two of 62 cases). In the current study, we found that absence of $p 16$ expression was identified in $10(30 \%)$ of 33 primary gastric lymphoma cases with promoter hypermethylation of the gene. In contrast, only one $(10 \%)$ of 10 cases with positive p16 immunostaining showed promoter hypermethylation. The lack of overall correlation between $p 16$ promoter hypermethylation and protein expression could be attributed to a large number of cases $(70 \%)$ in which lack of p16 protein expression was not accompanied by the presence of $p 16$ promoter methylation. Therefore, other mechanisms must contribute to the inactivation of $p 16$ gene in those primary gastric lymphomas, such as point mutation and/or gene deletion. In one case, p16 protein expression is accompanied by positive $p 16$ promoter methylation (Table 1). This has been previously documented in another study ${ }^{18}$ and could be due to intratumor heterogeneity of methylation pattern or the presence of minor component of tumor cells that showed epigenetic silencing of the $p 16$ gene. Nevertheless, these results indicate that approximately 
one-third of p16 inactivation correlated with promoter hypermethylation and suggest that epigenetic silence of tumor-suppressive gene may play a role in tumorigenesis of those primary gastric lymphomas.

BCL10, an apoptosis regulatory molecule containing an amino-terminal caspase-recruitment domain, is overexpressed as a result of $\mathrm{t}(1 ; 14)$ (p22;q32), a translocation that is also recurrently detected in a subgroup of MALT lymphomas. Abnormal nuclear expression of BCL10 and the $t(11 ; 18)$ translocation tend to appear together, and their joint occurrence is associated with advanced MALT lymphoma. ${ }^{21,37}$ The present study also suggests that the absence of p16 expression appears to be correlated with nuclear expression of BCL10 in these lymphomas from our previous study (manuscript in preparation). ${ }^{16}$ Six $(67 \%)$ of nine cases that expressed the p16 protein were negative for BCL10 expression, whereas $22(65 \%)$ of 34 case that were negative for the p16 protein expressed the BCL10 gene. However, no statistic significance can be obtained based on the relatively small number of case studies. Therefore, the exact relationship between $p 16$ gene inactivation and BCL10 expression remains unclear.

Although lack of p16 protein expression is present in the majority of the primary gastric lymphomas, there is no significant difference between p16 positive or negative primary gastric lymphomas with regard to the frequency of extragastric involvement at the time of resection. Inactivation of $p 16$ gene does not appear to be correlated with extragastric involvement in these patients. However, this view may even be of less significance due to not only the small number of cases analyzed but also limited pathologic data available for statistical analysis. More studies are needed to further establish the exact roles of $p 16$ inactivation in the development of primary gastric lymphomas.

In summary, we found that loss of p16 protein expression was seen in up to $79 \%$ of the primary gastric lymphomas and that approximately onethird of loss of p16 protein expression was associated with promoter hypermethylation. Despite limited pathologic data, loss of p16 protein expression appears not to be correlated with extragastric involvements.

\section{References}

1 Rocco JW, Sidransky D. p16 (MTS-1/CDKN2/INK4a) in cancer progression. Exp Cell Res 2001;264:42-55.

2 Ruas M, Peters G. The p16INK4a/CDKN2A tumor suppressor and its relatives. Biochim Biophys Acta 1998;1378:F115-F177.

3 Serrano M, Hannon GJ, Beach D. A new regulatory motif in cell-cycle control causing specific inhibition of cyclin D/CDK4. Nature 1993;366:704-707.

4 Serrano M, Lee H, Chin L, et al. Role of the INK4a locus in tumor suppression and cell mortality. Cell 1996;85:27-37.
5 Herman JG, Baylin SB. Promoter-region hypermethylation and gene silencing in human cancer. In: Vogt PAJaPK (ed). DNA Methylation and Cancer, 1st edn. Springer-Verlag: New York, Berlin, Heidelberg, 2000, pp. 35-50.

6 Cairns P, Polascik TJ, Eby Y, et al. Frequency of homozygous deletion at p16/CDKN2 in primary human tumours. Nat Genet 1995;11:210-212.

7 Heinzel PA, Balaram P, Bernard HU. Mutations and polymorphisms in the p53, p21 and p16 genes in oral carcinomas of Indian betel quid chewers. Int J Cancer 1996;68:420-423.

8 Sanchez-Cespedes M, Esteller M, Wu L, et al. Gene promoter hypermethylation in tumors and serum of head and neck cancer patients. Cancer Res 2000;60:892-895.

9 El-Naggar AK, Lai S, Clayman G, et al. Methylation, a major mechanism of p16/CDKN2 gene inactivation in head and neck squamous carcinoma. Am J Pathol 1997;151:1767-1774.

10 Esteller M, Gonzalez S, Risques RA, et al. K-ras and p16 aberrations confer poor prognosis in human colorectal cancer. J Clin Oncol 2001;19:299-304; (see comments).

11 Reznikoff CA, Yeager TR, Belair CD, et al. Elevated p16 at senescence and loss of p16 at immortalization in human papillomavirus 16 E6, but not E7, transformed human uroepithelial cells. Cancer Res 1996;56: 2886-2890.

$12 \mathrm{Kim} \mathrm{DH}$, Nelson HH, Wiencke JK, et al. p16(INK4a) and histology-specific methylation of $\mathrm{CpG}$ islands by exposure to tobacco smoke in non-small cell lung cancer. Cancer Res 2001;61:3419-3424.

13 Bai M, Vlachonikolis J, Agnantis NJ, et al. Low expression of p27 protein combined with altered p53 and RB/p16 expression status is associated with increased expression of cyclin A and cyclin B1 in diffuse large cell lymphomas. Mod Pathol 2001;14: 1105-1113.

14 Gronbaek K, de Nully Brown P, Moller MB, et al. Concurrent disruption of p16INK4a and the ARF-p53 pathway predicts poor prognosis in aggressive non-Hodgkin's lymphoma. Leukemia 2000;14: 1727-1735.

15 Rosas SLB, Koch W, Carvalho MDC, et al. Promoter hypermethylation patterns of p16, O6-methylguanineDNA methyltransferase, and death-associated protein kinase in tumors and saliva of head and neck cancer patients. Cancer Res 2001;61:939-942.

16 Zhang ZY, Weiss LW, Vardiman JW, et al. Histologic and immunophenotypic features of 46 cases of primary gastric lymphoma from China. Mod Pathol 2002;15: A1126 (abstract).

17 Isaacson PG, Muller-Hermelink HK, Piris MA, et al. Extranodal marginal zone B-cell lymphoma of mucosaassociated lymphoid tissue (MALT lymphoma). In: Jaffe ES, Harris NL, Stein H (eds). Pathology and Genetics: Tumor of Haematopoietic and Lymphoid Tissues. WHO Classification of Tumors. IARC Press: Lyon, 2001, pp. 157-160.

18 Ai L, Stephenson KK, Ling W, et al. The p16 (CDKN2a/ INK4a) tumor-suppressor gene in head and neck squamous cell carcinoma: a promoter methylation and protein expression study in 100 cases. Mod Pathol 2003;16:944-950.

19 Liu K, Zuo C, Luo QK, et al. Promoter hypermethylation and inactivation of hMLH1, a DNA mismatch 
repair gene, in head and neck squamous cell carcinoma. Diagn Mol Pathol 2003;12:50-56.

$20 \mathrm{Du}$ MQ, Isaccson PG. Gastric MALT lymphoma: from aetiology to treatment. Lancet Oncol 2002;3:97-104.

21 Liu H, Ye H, Dogan A, et al. T(11;18)(q21;q21) is associated with advanced mucosa-associated lymphoid tissue lymphoma that expresses nuclear BCL10. Blood 2001;98:1182-1187.

22 Starostik P, Patzner J, Greiner A, et al. Gastric marginal zone B-cell lymphomas of MALT type develop along 2 distinct pathogenetic pathways. Blood 2002;99:3-9.

$23 \mathrm{Du}$ MQ, Peng H, Liu H, et al. BCL10 gene mutation in lymphoma. Blood 2000;95:3885-3890.

24 Sanchez-Beato M, Saez AI, Navas IC, et al. Overall survival in aggressive B-cell lymphomas is dependent on the accumulation of alterations in p53, p16, and p27. Am J Pathol 2001;159:205-213.

25 Dalle JH, Fournier M, Nelken B, et al. P16INK4a immunocytochemical analysis is an independent prognostic factor in childhood acute lymphoblastic leukemia. Blood 2001;99:2620-2623.

26 Child FJ, Scarisbrick JJ, Calnje E, et al. Inactivation of tumor suppressor genes p15(INK4b) and p16(INK4a) in primary cutaneous B cell lymphoma. J Invest Dermatol 2002;118:941-948.

27 Han S, Ahn SH, Park K, et al. P16INK4a protein expression is associated with poor survival of the breast cancer patients after CMF chemotherapy. Breast Cancer Res Treat 2001;70:205-212.

28 Straume O, Akslen LA. Alterations and prognostic significance of p16 and p53 protein expression in subgroups of cutaneous melanoma. Int J Cancer 1997;74:535-537.
29 Straume O, Sviland L, Akslen LA. Loss of nuclear p16 protein expression correlates with increased tumor cell proliferation (Ki-67) and poor prognosis in patients with vertical growth phase melanoma. Clin Cancer Res 2000;6:1845-1853.

30 Newcomb EW, Cohen H, Lee SR, et al. Survival of patients with glioblastoma multiforme is not influenced by altered expression of p16, p53, EGFR, MDM2 or Bcl-2 genes. Brain Pathol 1998;8:55-67.

31 Miettinen H, Kononen J, Sallinen P, et al. CDKN2/p16 predicts survival in oligodendrogliomas: comparison with astrocytomas. J Neuro-Oncol 1999;41:205-211.

32 Bova RJ, Quinn DI, Nankervis JS, et al. Cyclin D1 and p16INK4a expression predict reduced survival in carcinoma of the anterior tongue. Clin Cancer Res 1999;5:2810-2819.

33 Kwong J, Lo KW, To KF, et al. Promoter hypermethylation of multiple genes in nasopharyngeal carcinoma. Clin Cancer Res 2002;8:131-137.

34 Navas IC, Algara P, Mateo M, et al. p16 (INK4a) is selectively silenced in the tumoral progression of mycosis fungoides. Lab Invest 2002;82:123-132.

35 Kim YS, Kim JS, Jung HC, et al. Regression of lowgrade gastric mucosa-associated lymphoid tissue lymphoma after eradication of Helicobacter pylori: possible association with p16 hypermethylation. J Gastroent 2002;37:17-22.

36 Sanchez-Beato M, Sanchez-Aguilera A, Piris MA. Cell cycle deregulation in B-cell lymphomas (review). Blood 2003;101:1220-1235.

37 Willis TG, Jadayel DM, Du MQ, et al. Bcl10 is involved in $\mathrm{t}(1 ; 14)(\mathrm{p} 22 ; \mathrm{q} 32)$ of MALT B cell lymphoma and mutated in multiple tumor types. Cell 1999;96:35-45. 